\title{
Aesthetic Concept - Choreography of Piso Surit Dance in Karo Community
}

\section{Dilinar Adlin}

Dance Education Study Program, Faculty of Languages and Arts, Universitas Negeri Medan, Medan, Indonesia dilinaradlinmpd@gmail.com

\begin{abstract}
Piso Surit dance in Karo community has distinctive characteristics in its movement techniques, floor patterns, environmental ethical norms, and symbolic-philosophical images. All of these characteristics grow and develop in line with aspects of the living environment that have been integrated in each form of art. This study aims to explain: 1) the basis and rules of Piso Surit dance; and 2) the concept of Piso Surit dance choreography. This study uses a choreographic-anthropological approach, which is to analyze the relationship of dance motion with the aesthetic choreographic concept of Piso Surit dance and Karo community's mindset. Observation, documentation, and interview techniques are used to collect data and then the triangulation data analysis process is carried out to obtain the credibility of the data. The results showed that the rules for the use and application of motive motives fall into two categories, namely for male dancers and female dancers. The application of the prevailing floor pattern is dealing with their partners, side by side, and encircling each other. The rules for the use and application of accompaniment patterns intend to create a unified nature that is subtle, gentle, and harmonious. In the concept of choreography, Piso Surit's dance movements are broken down into nine (9) sections. The movements use techniques such as: a) tiptoeing, b) rotating movements, c) stopping fingers, and d) up and down movements. The music used as accompaniment in the Piso Surit dance is a folk song in Karo area with the same title. This dance uses 'beautiful' make-up to emphasize the dancer's facial lines in a dance performance, while the fashion is a dress code as used by Karo community. As a pair dance, the floor pattern applied is to show or emphasize the story of how young Karo young people combine love.
\end{abstract}

\section{Keywords}

Piso Surit dance; aesthetic concept; choreography concept

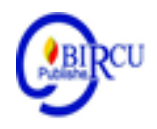

\section{Introduction}

Tradition is always interpreted as everything that is inherited from the past. As part of tradition, art is a series of activities from the culture of the people who cannot stand alone. Art life of each ethnic group is closely related to religious, linguistic, economic, and kinship aspects in which the arts live, grow and develop. In traditional societies, where the religious factors are very strong, art has a very important function and position and is a part of daily life. Harsoyo, (1967: 185) states that art, in addition to cultural, social and individual creativity, is also one of the essential factors for integration.

In traditional community life patterns, art shows the meaning of oneness or integration with its environment. The integration is manifested through the values of art as a binder of solidarity between citizens of their communities. In this context, traditional arts with various forms and motives, can not be seen as a part that is separated from the supporting community, 
but become an integral part of the socio-cultural dynamics of the community. These cultural habits cover all aspects of culture, whether religion, language, customs, patterns of community regulation, kinship systems, or the arts.

Dance, as one form of art is inseparable from the context of the problem of art in the community. Traditional dance is the work of human creation and inventiveness which is passed on from one generation to the next. A traditional dance style does not remain in shape. He will always change when taught by the previous generation to the next generation, because the form of dance that is inherited must be interpreted. Traditional dance will continue to be preserved if there is continuous renewal and development by its supporters. Development and renewal can be done by individuals or groups, either in the form of internal perceptions or external perceptions.

Interested in understanding the background of life patterns and movement arrangements in the Piso Surit dance, this research will explore and describe with more aesthetic and choreographic concepts of Piso Surit dance in Karo community. Karo community is one of several Batak sub-tribes in North Sumatra. Karo is also a term for one administrative region of the Regency, namely Karo Regency, which covers the entire Karo plateau

The Piso Surit dance in Karo community has distinctive characteristics in its movement techniques, floor patterns, environmental ethical norms, and symbolicphilosophical images. All of these characteristics grow and develop in line with aspects of the living environment that have been integrated in each form of art. Thus, the Piso Surit dance in Karo community actually reflects the distinctive color of the environment, including philosophical, norms and ethical aspects, pedagogical elements, and ideologies that develop in the community. This study uses a Choreographic-Anthropological approach to the focus under study, namely the relationship of the aesthetic choreographic concept of Piso Surit dance that is related to the mindset of the Karo people. The use of this approach aims to have the data collected as valid data, while the method chosen is descriptive qualitative method.

\section{Review of Literature}

Piso Surit dance is one of the traditional dances owned by Karo Batak people in North Sumatera. This dance is a welcome dance that is displayed in pairs in groups by dancers, both men and women or women and women. So far the creator of this dance has not been found, because it is owned communally by the community. From several sources, the name of the dance is taken from the word 'Piso Surit', which is the name of a type of bird in Karo language, which likes to sing. In terms of dance moves, this dance reflects a person's waiting for his lover. The wait is likened to a surit peso that sounds like calling out. This dance moves are characteristic and graceful, felt like done repeatedly, even though it is actually different. The movements or types of dance that can be found in this dance include: the movements of the feet on tiptoes, the rotating movements, stopping fingers, up and down movements, and other movements. The following will be explained in more detail.

\subsection{Basic and Rules}

\section{Rules of Use and Application of Motion Motives}

In general, the basic patterns of Karo dance have their respective movements, both for male dancers and female dancers. The following is an explanation of these rules.

For male dancers have the following rules of motion:

- Both hands on the face are shoulder level with palms facing the sky. 
- Both hands are parallel to the shoulders, palms facing towards the face to the dancing opponent.

- Every change of pattern is done picking, i.e., the position of the fist in chest face.

- Left hand above shoulder with palm position towards the sky, while the right hand is parallel to the hip.

For female dancers, have the following rules of motion:

- Both hands in front of the shoulders are parallel to the position of the palms towards the dancing opponent.

- Both hands are parallel to the hips while the palms are pointing down.

- Every change of pattern is done picking, that is, arms crossed on the face stomach / center.

- Both hands are parallel to the hips with palms pointing toward the sky. The whole variety can be seen in more detail in the table below.

Table 1. Karo Dance Rules of Procedure

\begin{tabular}{|c|l|l|}
\hline \multicolumn{2}{|c|}{ MALE DANCER } \\
\hline No & \multicolumn{1}{|c|}{ Motion Rules } \\
\hline 1 & $\begin{array}{l}\text { Both hands in front of the shoulders are } \\
\text { parallel to the shoulders with the palms } \\
\text { towards the sky. }\end{array}$ & $\begin{array}{l}\text { Both hands in front of the shoulders are } \\
\text { parallel to the shoulders, palms pointing } \\
\text { towards the dance opponent. }\end{array}$ \\
\hline 3 & $\begin{array}{l}\text { Every change of pattern is done picking, } \\
\text { namely the position of the fist in the face } \\
\text { of the chest. }\end{array}$ \\
\hline
\end{tabular}




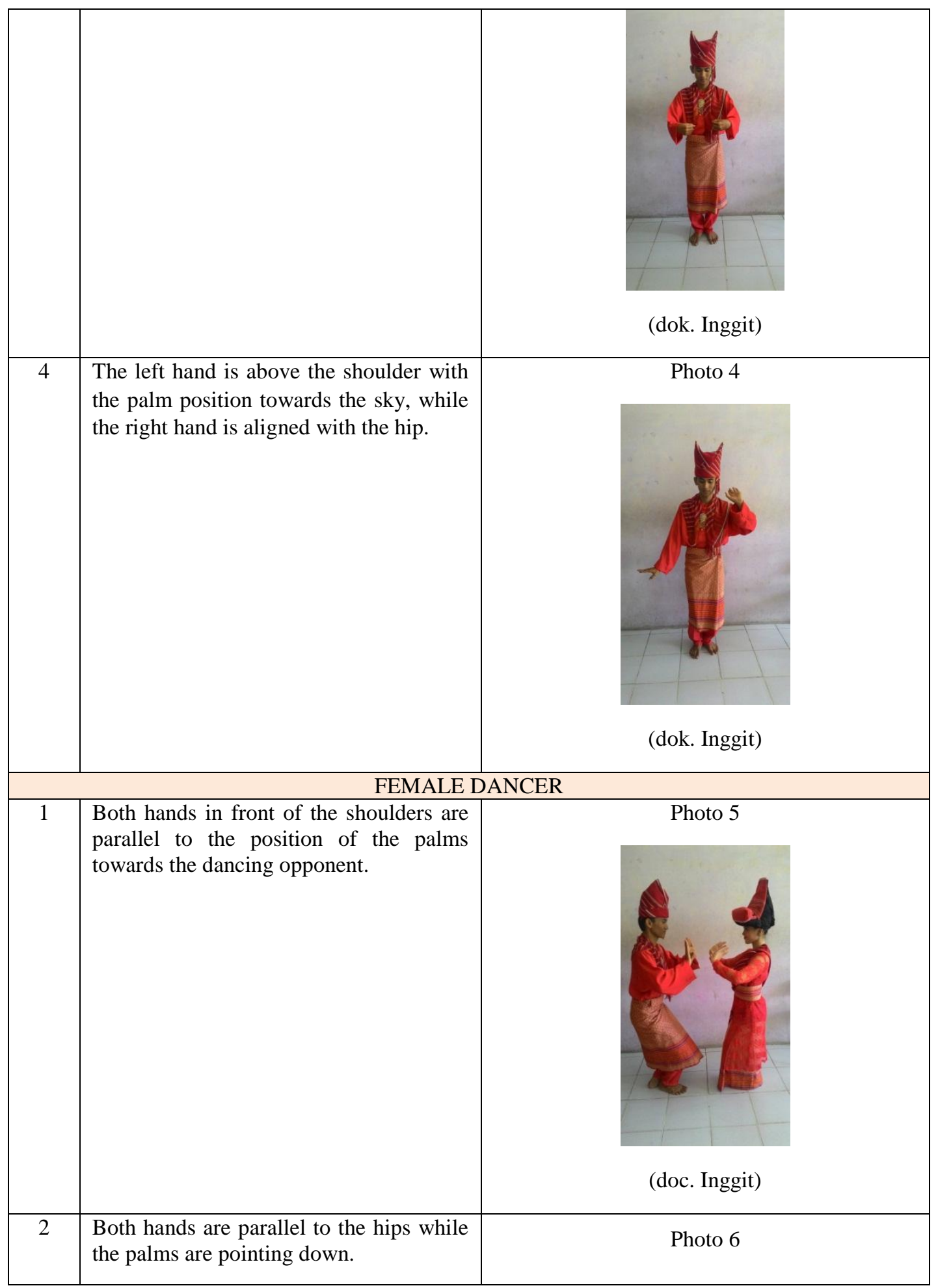




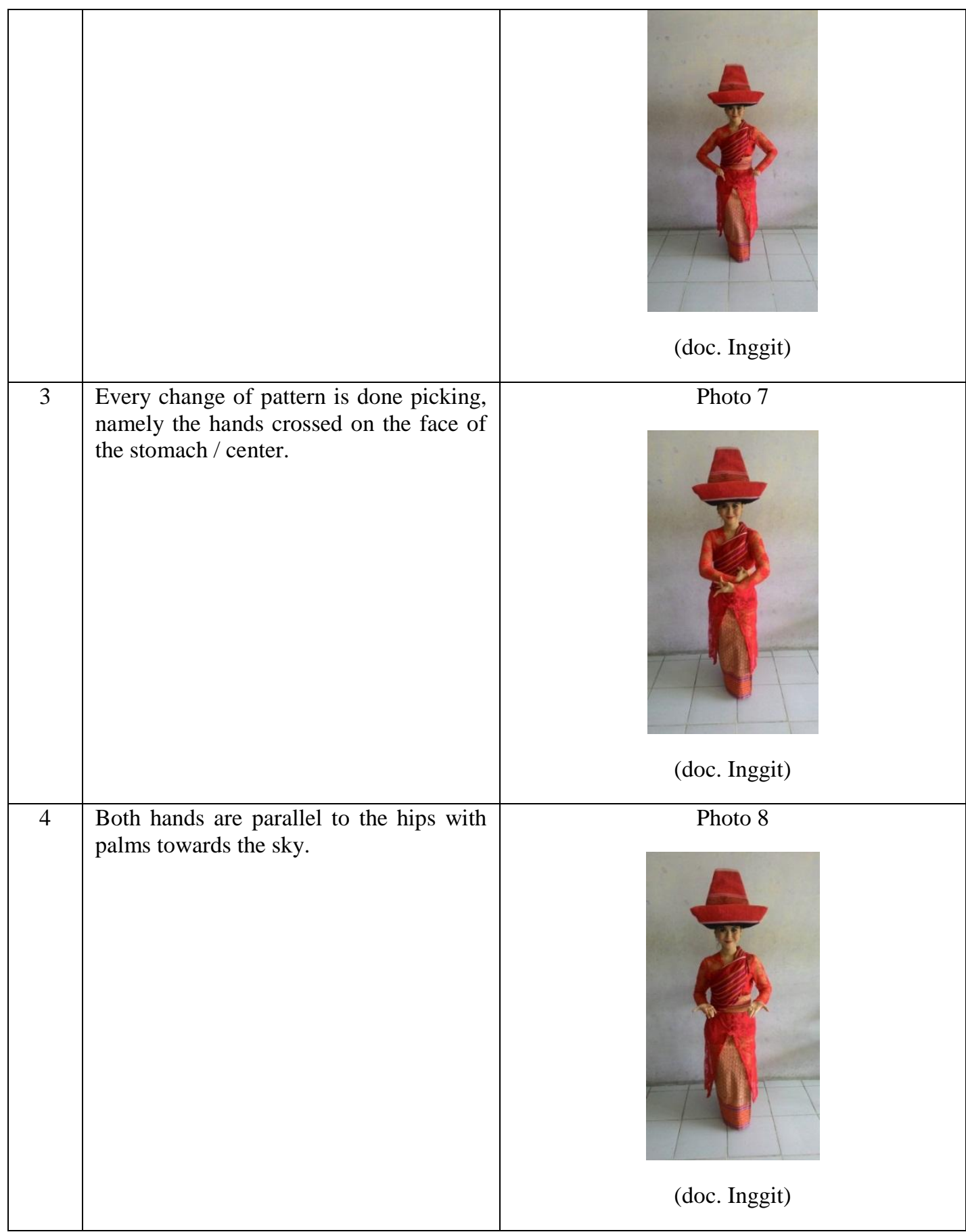

\subsection{Rules for the Implementation of Floor Patterns}

The rules in the form of normative provisions in the use and application of floor patterns in the composition of the Piso Surit dance are still valid, such as dealing with a partner, side by side, and encircling each other which is then repeated. These habits and provisions are still maintained in the preparation of new dance patterns in Karo community.

In the Piso Surit dance, the rules of the floor pattern are the principle. Some repetition of floor patterns can be analogous to understanding the repetition of Bedhaya dance floor patterns in Java. This understanding conveys that, the repetition of floor patterns is because 
philosophically the patterns of human thought are not always permanent, but repeatedly or constantly changing. The following will be explained in more detail in the table below.

Table 2. Application of the Piso Surit Dance Floor Pattern

\begin{tabular}{|c|c|c|}
\hline No & Floor pattern shape & Photo \\
\hline 1 & Face to face & $\begin{array}{l}\text { Photo } 9 \\
\end{array}$ \\
\hline 2 & Side by side & dok. Inggit) \\
\hline 3 & Side by side opposite & dok. Inggit) \\
\hline
\end{tabular}




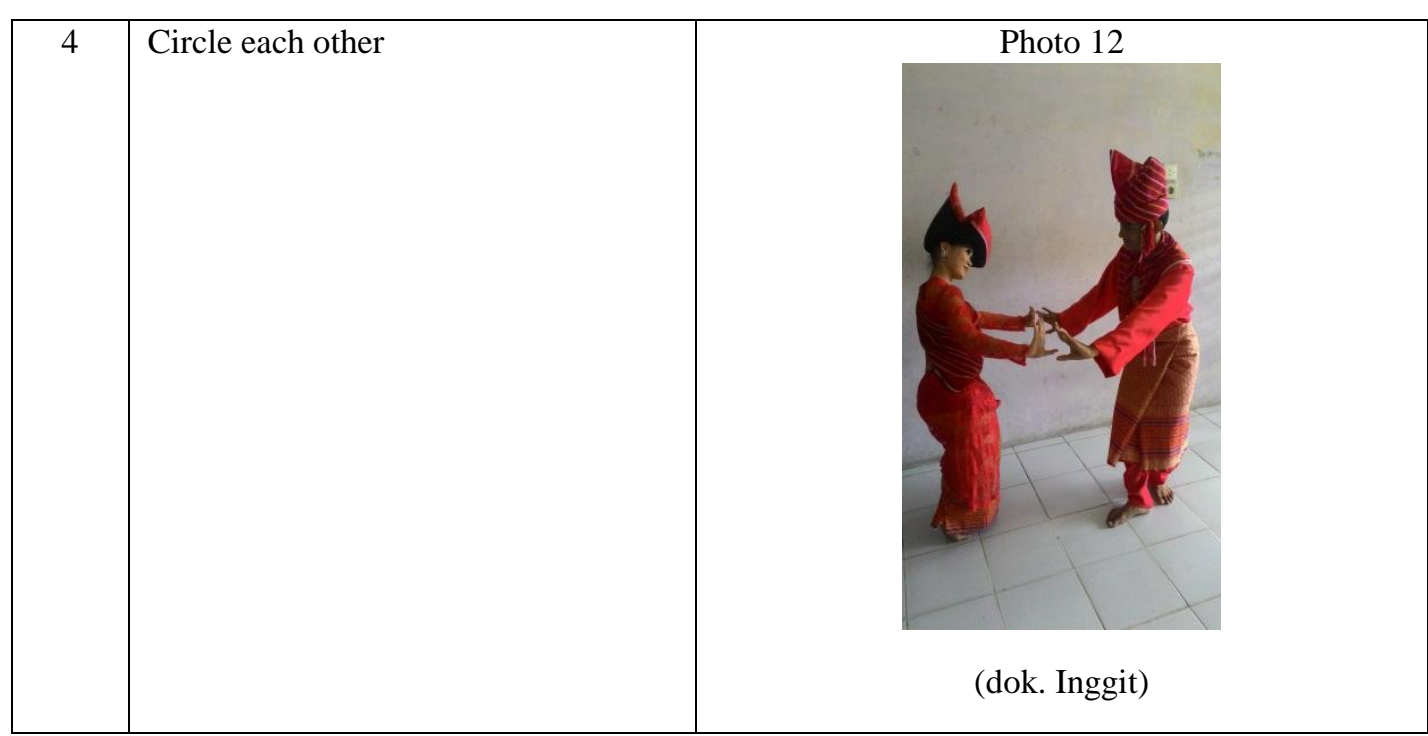

As a cycle, the application of the Piso Surit dance floor pattern depicts the story to be conveyed to the audience, namely how a person waits for his lover who is shown through his song poetry, succeeding with happiness. Beginning togetherness that presents a sense of love, continued with the achievement of harmony, and ended with oneness.

\subsection{Rules for the Use and Application of Accompaniment Patterns}

In dance, 'rhythm of motion' and 'rhythm of motion' store important meanings. The rhythm of motion and rhythm of motion have a close relationship with the technique of performing dance movements and patterns of motion. In other words, all movements in dance are patterned and arranged in attachment to the rhythm of the movements and the rhythm of the movements. This attachment will be seen and felt in every use of movement speed, intensity of motion, force of motion, principle of balance, and use of energy in motion. Thus, the rhythm of motion and rhythm of motion have a close understanding.

Rhythm can be interpreted as fast or slow beats. In this case the speed or delay is fixed, and is determined by the grace period (tempo) used in each beat. Thus, what is meant by dance rhythm is the speed or slowness of a fixed-distance beat, to 'provide a limit' in using the intensity of the motion, the force of motion, the principle of balance, and the use of energy in motion.

The use of rhythmic motion will always be different in each form, style, and type of dance. In the normative provisions of the Piso Surit dance, the rhythm of the motion used is in harmony with the singing of the song that expresses the meaning of the words in this song, the song Piso Surit.

The principle of the Piso Surit dance movement is always done right at the beat, or under pressure. The application of this rhythm intends to realize a unified nature that is subtle, gentle, and harmonious. Thus, the intensity of the motion, the force of motion, the principle of balance, and the use of energy in motion become more organized and consistent. 


\section{Discussion}

\subsection{Choreography Concepts}

In general, what is meant by the concept of choreography are thoughts that are applied to realize the 'shape' and 'style' in a dance arrangement. These thoughts relate to many things in producing the composition of a dance. In this connection, this research will only explain the form of 'piso surit' dance through its dance movements, dance accompaniment, floor patterns, and fashion make-up.

\section{a. Piso Surit Dance Forms}

Overall, the Piso Surit dance movements are solved in nine (9) sections. Although in some parts there are repetitions, but if you look closely, you will find differences, but they will confirm the content of the story being told. These movements include: a) tiptoeing, b) rotating movements, c) stopping fingers, d) up and down movements, and other movements. If you pay close attention every movement in the dance certainly has a special meaning in it. To facilitate understanding of the range of motion contained in Piso Surit dance, the researchers arranged it in tabular form like the following:

Table 3. Description of Piso Surit Dance Movements

\begin{tabular}{|c|c|c|c|c|c|c|c|}
\hline \multirow{2}{*}{ No } & \multirow{2}{*}{$\begin{array}{c}\text { Variety of } \\
\text { Motion }\end{array}$} & \multirow{2}{*}{ The count } & \multicolumn{4}{|c|}{ Motion Engineering } & \multirow{2}{*}{ Floor pattern } \\
\hline & & & Feet & Hand & Body & Head & \\
\hline 1 & $\begin{array}{l}\text { Starting a } \\
\text { Movement }\end{array}$ & $3 \times 8$ & $\begin{array}{l}\text { Walking into } \\
\text { the dancing } \\
\text { arena, } \\
\text { starting with } \\
\text { the right foot }\end{array}$ & $\begin{array}{l}\text { Left hand on } \\
\text { shoulder, } \\
\text { right hand } \\
\text { on the side / } \\
\text { side of the } \\
\text { body }\end{array}$ & $\begin{array}{l}\text { Facing } \\
\text { forward }\end{array}$ & $\begin{array}{l}\text { Facing } \\
\text { forward }\end{array}$ & $\begin{array}{ll}\mathrm{X} & \mathrm{X} \\
& \\
\downarrow & \downarrow\end{array}$ \\
\hline 2 & $\begin{array}{l}\text { Rotate Right } \\
\text { and Rotate } \\
\text { Left }\end{array}$ & $\begin{array}{l}1 \times 8 \text { in } \\
\text { place } \\
1 \times 8 \text { rotate } \\
\text { left and } \\
\text { right }\end{array}$ & $\begin{array}{l}\text { Right foot } \\
\text { starts to } \\
\text { move }\end{array}$ & $\begin{array}{l}\text { Hands are } \\
\text { lifted from } \\
\text { the bottom, } \\
\text { rotated and } \\
\text { placed on } \\
\text { the shoulder }\end{array}$ & $\begin{array}{l}\text { Left and } \\
\text { right }\end{array}$ & $\begin{array}{l}\text { Look } \\
\text { forward, } \\
\text { look at the } \\
\text { hands, and } \\
\text { follow the } \\
\text { direction of } \\
\text { the body }\end{array}$ & $\mathrm{x} \rightarrow$ \\
\hline 3 & $\begin{array}{l}\text { Move to the } \\
\text { right and left }\end{array}$ & $3 \times 8$ & $\begin{array}{l}\text { The first foot } \\
\text { goes forward } \\
\text { and is } \\
\text { pushed back } \\
\text { and forward } \\
\text { to the left, } \\
\text { the right foot } \\
\text { is on, and } \\
\text { the forward } \\
\text { foot is } \\
\text { tiptoeed to } \\
\text { the left foot } \\
\text { back }\end{array}$ & $\begin{array}{l}\text { The right } \\
\text { hand is } \\
\text { rotated from } \\
\text { under the } \\
\text { left hand } \\
\text { also 5-8, } \\
\text { advancing to } \\
\text { the left, the } \\
\text { hand is } \\
\text { swung. }\end{array}$ & $\begin{array}{l}\text { Forward to } \\
\text { the right, } \\
\text { body } \\
\text { pointing } \\
\text { forward } \\
\text { and } \\
\text { towards } \\
\text { the pair }\end{array}$ & $\begin{array}{l}\text { Looking to a } \\
\text { partner }\end{array}$ & \\
\hline 4 & $\begin{array}{l}\text { Move } \\
\text { around, then } \\
\text { back }\end{array}$ & $3 \times 8$ & $\begin{array}{l}\text { Move to the } \\
\text { couple's } \\
\text { place, then } \\
\text { return to the } \\
\text { original }\end{array}$ & $\begin{array}{l}\text { Right hand } \\
\text { rotated down } \\
\text { and } \\
\text { sideways. } \\
\text { Both are }\end{array}$ & $\begin{array}{l}\text { The body } \\
\text { leads to the } \\
\text { pair, then } \\
\text { moves to } \\
\text { the right, }\end{array}$ & $\begin{array}{l}\text { Head in one } \\
\text { direction }\end{array}$ & \\
\hline
\end{tabular}




\begin{tabular}{|c|c|c|c|c|c|c|c|}
\hline & & & $\begin{array}{l}\text { place. } \\
\text { Starting with } \\
\text { the right } \\
\text { foot, turning } \\
\text { left }\end{array}$ & parallel. & $\begin{array}{l}\text { and back } \\
\text { again }\end{array}$ & & \\
\hline 5 & $\begin{array}{l}\text { Move to a } \\
\text { low position } \\
\text { (like } \\
\text { crouching) }\end{array}$ & $\begin{array}{l}4 \times 8 \\
\text { Left and } \\
\text { right }\end{array}$ & $\begin{array}{l}\text { Both feet on } \\
\text { tiptoe when } \\
\text { crouching, } \\
\text { then slowly } \\
\text { go back up }\end{array}$ & $\begin{array}{l}\text { Right hand } \\
\text { on the } \\
\text { shoulder, left } \\
\text { hand on the } \\
\text { side of the } \\
\text { body }\end{array}$ & $\begin{array}{l}\text { The body } \\
\text { follows the } \\
\text { direction } \\
\text { of the foot, } \\
\text { left and } \\
\text { right, } \\
\text { upright } \\
\text { position }\end{array}$ & $\begin{array}{l}\text { Head in one } \\
\text { direction }\end{array}$ & $\mathrm{x}$ \\
\hline 6 & $\begin{array}{l}\text { Move to the } \\
\text { right side, } \\
\text { and left, and } \\
\text { backward }\end{array}$ & $\begin{array}{l}1-4 \text { right } \\
5-8 \text { left } \\
\text { Be } \\
\text { repeated } 3 \\
\text { x } 8\end{array}$ & $\begin{array}{l}\text { Legs move } \\
\text { right, left, } \\
\text { and } \\
\text { backward } \\
\text { starting with } \\
\text { the right foot }\end{array}$ & $\begin{array}{l}\text { Right hand } \\
\text { rotated down } \\
\text { and } \\
\text { sideways. } \\
\text { Both are } \\
\text { parallel. }\end{array}$ & $\begin{array}{l}\text { Follow the } \\
\text { direction } \\
\text { of the foot, } \\
\text { then face } \\
\text { the pair }\end{array}$ & $\begin{array}{l}\text { In the } \\
\text { direction of } \\
\text { the body, } \\
\text { and facing } \\
\text { the front }\end{array}$ & $\begin{array}{l}\mathrm{x} \\
\downarrow\end{array}$ \\
\hline 7 & $\begin{array}{l}\text { Piso moves } \\
\text { right and left }\end{array}$ & $\begin{array}{l}1-4 \text { right } \\
5-8 \text { left } \\
\text { Be } \\
\text { repeated } 3 \\
\text { x } 8\end{array}$ & $\begin{array}{l}\text { Legs move } \\
\text { right, left, } \\
\text { and } \\
\text { backward } \\
\text { starting with } \\
\text { the right foot }\end{array}$ & $\begin{array}{l}\text { Right hand } \\
\text { rotated down } \\
\text { and } \\
\text { sideways. } \\
\text { Both are } \\
\text { parallel. }\end{array}$ & $\begin{array}{l}\text { Follow the } \\
\text { direction } \\
\text { of the foot, } \\
\text { then face } \\
\text { the pair }\end{array}$ & $\begin{array}{l}\text { In the } \\
\text { direction of } \\
\text { the body, } \\
\text { and facing } \\
\text { the front }\end{array}$ & \\
\hline 8 & $\begin{array}{l}\text { Rotate, } \\
\text { return to } \\
\text { original } \\
\text { place, then } \\
\text { right and left }\end{array}$ & $\begin{array}{l}1-4 \text { right } \\
5-8 \text { left }\end{array}$ & $\begin{array}{l}\text { Moving } \\
\text { places. }\end{array}$ & $\begin{array}{l}\text { Right hand } \\
\text { rotated down } \\
\text { and } \\
\text { sideways. } \\
\text { Both are } \\
\text { parallel. }\end{array}$ & $\begin{array}{l}\text { Follow the } \\
\text { direction } \\
\text { of the foot, } \\
\text { then face } \\
\text { the pair }\end{array}$ & $\begin{array}{l}\text { In the } \\
\text { direction of } \\
\text { the body, } \\
\text { and facing } \\
\text { the front }\end{array}$ & $\begin{array}{l}\mathrm{x} \rightarrow \leftarrow \mathrm{x} \\
\downarrow\end{array}$ \\
\hline 9 & $\begin{array}{l}\text { Exit (go } \\
\text { home) }\end{array}$ & $1 \times 8$ & $\begin{array}{l}\text { Starting with } \\
\text { the right } \\
\text { foot, } \\
\text { walking } \\
\text { while being } \\
\text { driven }\end{array}$ & $\begin{array}{l}\text { Right hand } \\
\text { rotated down } \\
\text { and } \\
\text { sideways. } \\
\text { Both are } \\
\text { parallel. }\end{array}$ & $\begin{array}{l}\text { Follow the } \\
\text { direction } \\
\text { of the foot, } \\
\text { then face } \\
\text { the pair }\end{array}$ & $\begin{array}{l}\text { In the } \\
\text { direction of } \\
\text { the body, } \\
\text { and facing } \\
\text { the front }\end{array}$ & $\begin{array}{l}\uparrow \\
\mathrm{x}\end{array}$ \\
\hline
\end{tabular}

\subsection{Dance Accompaniment}

Piso Surit dance is accompanied by a set of traditional Karo musical instruments, but in its development, this dance often uses a modern musical instrument, the 'keyboard', which is now part of the traditional music played in Karo. The inclusion of the 'keyboard' instrument became part of the Karo traditional musical instrument, causing a change to the title 'Karo keyboard drum' to describe the modern Karo music used to accompany Karo songs. The music used as an accompaniment in the Piso Surit dance was originally a folk song in the Karo area, which was then used as a dance accompaniment. So that as a people's property, the dance movements are not standard, but still meet Karo regional dance standard.

The song Piso Surit, composed by national composer Djaga Depari from Seberaya Village, is the personification of the 'pincala' bird sound. The chirping of the loud 'pincala' and the bear-bear during the evening became Djaga Depari's inspiration to compose the song Piso Surit, the lyrics of which tell about the waiting of a Karo girl for her lover, and at the 
same time illustrate how young Karo young people combined love in earlier times. Here are the poems of the song Piso Surit.

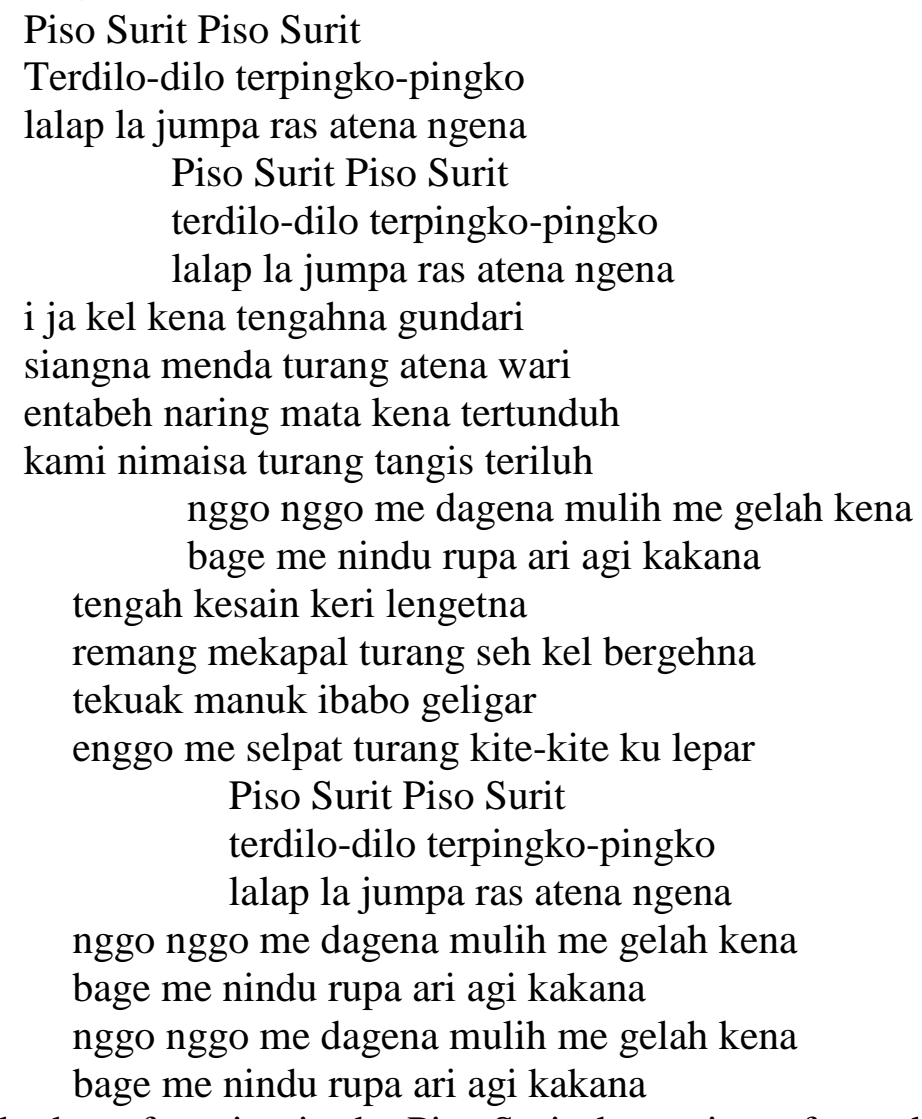

The use of the rhythm of motion in the Piso Surit dance, is performed precisely on the beat, which in dance terms is often referred to as 'on the beat'. The use of the rhythm of this movement is intended to show that the content is intended to realize the unity of gentle and lulut traits in the Karo dance movement, especially in the Piso Surit dance.

\subsection{Makeup and Clothing}

The make up and fashion applied in the Piso Surit dance are not fixed. This is because this dance is a folk dance, so the form of fashion and makeup depends on the will of the culprit. However, in general, this dance uses 'beautiful' make up which is used to emphasize the dancer's facial lines for a dance performance, while the fashion is the fashion as used by the Karo people, as follows:

a. Female Dancers:

- Using kebaya (usually red)

- 'Uis' is a typical Karo cloth used as an 'abit' or long bottom cloth

- 'Hood' or head cover, and

- Shawl

b. Male Dancers:

- Using a shirt (usually white)

- Using trousers (usually black)

- 'Uis' as a gonje or sheath, and a bow or waist strap 
- Shawl from uis Nipes

- Head cover

\subsection{Piso Surit Dance Floor Pattern}

The floor pattern used in this dance is generally the same for each show, although it is carried out by different regions. As a paired dance that depicts couples who are making love, the floor pattern applied is to show or confirm the story of how young Karo youths are making love.

The use of non-binding performance spaces, such as the proscenium stage or arena performances, shows the harmony between the dance moves and the form of the performance space. The combination of floor patterns that often confront and use straight lines, gives the impression of a firm stand for the choice of heart. The soft and supple motion of dancers, with the solid space of the proscenium stage, shows the balance of life, as well as its integration with an open arena space, which implies the extent and magnitude of outside influences, increasingly showing that determination will be stronger by opening up opportunities for receive input from various sources.

\section{Conclusion}

The results of the research so far are the availability of documents about one of the Karo traditional dances, Piso Surit dance. Although writing about this dance has been found with a variety of topics, but this study chose a topic that had never been written before, namely the study of the aesthetic choreographic concepts in Piso surit dance. This document is important, especially for dance study programs to be used as a data bank on traditional dance owned by the people of North Sumatra, especially Karo community. In addition, through this research written documents about dance owned by the Karo community, specifically Piso Surit dance, are getting richer in various study topics.

\section{References}

Siburian, Pt Esra. (2019). Music in Perumah Begu Ritual of Karo Tribe (Study of Form and Music Functions). Budapest International Research and Critics Institute (BIRCIJournal) : Humanities, 313-320.

Murgiyanto, Sal, 1983. Koreografi. Pengatahun Dasar Komposisi Tari. Jakarta ;

Depdikbud

, 2004.Tradisi Dan Inovasi. Beberapa Masalah Tari di Indonesia, Jakarta ; Wedatama Widya Sastra

Sedyawati, Edi, 1981. Pertumbuhan Seni Pertunjukan, Jakarta; Sinar Harapan , 1981. Seni Dalam Masyarakat Indonesia, Jakarta ; Sinar Harapan

Sedyawati, Edi. 1981. Tari : Tinjauan Seni Pertunjukan, Jakarta : Dunia Pustaka Jaya.

et al. 1986. "Tari Sebagai Salah Satu Pernyataan Budaya" dalam Fx Sutopo Cokrohamijoyo, et.al. (ed). Pengetahuan Elementer Tari dan Beberapa Masalah Tari. Jakarta: Direktorat Kesenian Departemen Pendidikan dan Kebudayaan. 